\title{
Narkosens egen sykdom
}

Moderne narkose er trygt og medfører ytterst sjelden livstruende komplikasjoner (1). Modernisering har foregått på flere områder parallelt; vi har bedre utstyr for pasientovervåking og medikamenttilførsel under og etter operasjonen, økt innsikt i perioperativ patofysiologi og tryggere og mer styrbare medikamenter for sikring av søvn, smertelindring og muskelrelaksasjon. Generelt har vi sett en overgang fra «tunge» inhalasjonsanestesier, der nevromuskulært blokkerende medikamenter nærmest alltid inngikk, til totalt intravenøse teknikker. Like fullt er gassbasert anestesi stadig vanlig i Norge og er den dominerende teknikken i mange vestlige land.

Malign hypertermi er en sjelden tilstand, som kan utløses av halogenerte anestesigasser og av depolariserende nevromuskulære blokkere. Av halogenerte gasser er tre i bruk i Norge i dag: sevofluran, desfluran og isofluran, mens suksinylkolin (Curacit) er den eneste anvendte depolariserende nevromuskulære blokkeren. Anestesigassene gis kontinuerlig for å sikre søvn og analgesi under kirurgi, mens suksinylkolin i dag hovedsakelig brukes for raskt å sikre kontroll over luftveien ved aspirasjonsfare (rapid-sequenceinduction). Suksinylkolin vil således benyttes i mange øyeblikkelig hjelp-situasjoner, for eksempel ved keisersnitt i narkose.

Klinisk manifestasjon av malign hypertermi, slik kollegene ved Akershus universitetssykehus beskriver, betinger foruten utløsende medikamenter, også en genetisk predisposisjon hos den aktuelle pasienten. Det er til nå beskrevet flere titalls sykdomsassosierte mutasjoner i gener som koder for ryanodin- og/eller dihydropyridinreseptoren $(2,3)$, og data tyder på at forekomsten av slike predisponerende genmutasjoner kan være så høy som 1:3000 i vestlige populasjoner (4). Arvegangen er autosomalt dominant med sterkt varierende og uforutsigbar penetrans, slik at potensielt utsatte pasienter vil være langt færre.

Som Martin og medarbeidere her beskriver, vil det ikke sjelden være uklart om den oppståtte kliniske situasjonen er uttrykk for malign hypertermi-disposisjon eller ikke. For å unngå potensielt livstruende komplikasjoner ved fremtidige narkoser, er det avgjørende å avklare dette. Korrekt informasjon til pasienten er i denne sammenhengen også viktig. Norske anestesiologer utsteder rutinemessig et standardisert «anestesiproblemkort» i lommebokformat til pasienter som har opplevd potensielt farlige anestesikomplikasjoner, herunder malign hypertermi.

Genetisk testing avklarer ikke hvorvidt en pasient er disponert for denne tilstanden eller ikke. Til det behøves in vitro kontrak- turtesting av muskelbiopsi i kaffein- eller halotanbad, et tilbud som dessverre for tiden ikke foreligger i Norge. Norske pasienter kan i stedet tilbys utredning ved Herlev hospital (København) eller Universitetssjukhuset i Lund. Dette gjøres i meget liten grad. I Herlev har man bare fått henvist én norsk pasient, mens man i Lund har hatt et ensifret antall norske pasienter til utredning de senere år (D. Bendixen, G. Islander, personlig meddelelse). Til sammenlikning utredes 70-90 henviste personer på hvert av de to sentrene årlig. Ved Herlev fikk 15 av de 87 personene som ble testet siste 12 måneder, bekreftet at de er disponert for malign hypertermi, mens de resterende 72 fikk diagnosen avkreftet. I Lund har man om lag 50\% positive testresultater. Den dominante arvegangen gjør at også nære slektninger av kjente malign hypertermi-disponerte individer vurderes for utredning.

Manglende utredning medfører altså at norske pasienter som mistenkes å ha hatt en episode med klinisk malign hypertermi og deres nærmeste slektninger, bare unntaksvis får avklart om de er reelt disponerte for denne livstruende tilstanden ved fremtidige narkoser. Uvisshet om dette kan også ha andre konsekvenser: I Sverige blir malign hypertermi-disponerte personer avvist for en yrkesmilitær karriere. Det er på høy tid å få reorganisert et nasjonalt testlaboratorium i Norge. Den nødvendige kompetansen og utstyret finnes til dels fremdeles i landet.

Man vil kunne innvende at malign hypertermi kan omgås simpelthen ved alltid å unngå utløsende agens og heller anvende trygge medikamenter, som sovemidlet propofol. Imidlertid fins det holdepunkter for at gassbaserte teknikker kan være fordelaktige for eksempel innen hjerteanestesi, og ved narkoseinnledning hos barn uten intravenøs tilgang har inhalasjonsmidlene en selvsagt plass. Anestesigassene vil derfor trolig være i bruk i overskuelig fremtid. For det andre utløsende medikamentet, suksinylkolin, vil situasjonen kunne bli annerledes. Innen kort tid markedsføres sannsynligvis et nytt legemiddel (Sugammadex), som reverserer enkelte ikke-depolariserende nevromuskulære blokkere raskt og forutsigbart. Det er et berettiget håp om at suksinylkolin med dets mange problemer om ikke altfor lenge vil kunne henvises til historiebøkene. Malign hypertermi, derimot, er en sykdom også fremtidige anestesiologer vil måtte forholde seg til.

\section{Siv Cathrine Høymork}

s.c.hoymork@medisin.uio.no

Anestesiavdelingen

Sykehuset Asker og Bærum

1309 Rud
Oppgitte interessekonflikter: Ingen

Litteratur

1. Botney R. Improving patient safety in anesthesia: a success story? Int J Radiat Oncol Biol Phys 2008 71: S182-6.

2. Larach MG, Brandom BW, Allen GC et al. Cardiac arrests and deaths associated with malignant hyperthermia in North America from 1987 to 2006: a report from the North American malignant hyperthermia registry of the malignant hyperthermia association of the United States. Anesthesiology 2008; 108: 603-11.

3. Rosenberg H, Davis M, James D et al. Malignant hyperthermia. Orphanet J Rare Dis 2007; 2: 21.

4. Monnier N, Kozak-Ribbens G, Krivosic-Horber R et al. Correlations between genotype and pharmacological, histological, functional, and clinical phenotypes in malignant hyperthermia susceptibility. Hum Mutat 2005; 26: 413-25.

Manuskriptet ble mottatt 24.6. 2008 og godkjent 18.11. 2008. Medisinsk redaktør Odd Terje Brustugun. 